\title{
Leucine metabolism in regulation of insulin secretion from pancreatic beta cells
}

\author{
Jichun Yang ${ }^{1,}{ }^{,}$, Yujing Chi ${ }^{1}$, Brant R. Burkhardt ${ }^{2}$, Youfei Guan ${ }^{1}$, and Bryan A Wolf ${ }^{2}$ \\ ${ }^{1}$ Department of Physiology and Pathophysiology, Peking University Diabetes Center, Peking \\ University Health Science Center, Beijing 100191, China \\ 2 Department of Pathology and Laboratory Medicine, The Children's Hospital of Philadelphia and \\ University of Pennsylvania School of Medicine, Philadelphia, PA 19104
}

\begin{abstract}
Leucine, a the branched-chain amino acids that must be supplied in daily diet, plays an important role in controlling protein synthesis and regulating cell metabolism in various cell types. In pancreatic $\beta$ cells, leucine acutely stimulates insulin secretion by serving as both metabolic fuel and allosteric activator of glutamate dehydrogenase to enhance glutaminolysis. Leucine has also been shown to regulate gene transcription and protein synthesis in pancreatic islet $\beta$ cells via both mTOR-dependent and -independent pathways at physiological concentrations. Long-term treatment of leucine has been shown to improve insulin secretory dysfunction of human diabetic islets via upregulation of certain key metabolic genes. In vivo, leucine administration improves glycemic control in humans and rodents with type 2 diabetes. This review aims to summarize and discuss the recent findings regarding the effects of leucine metabolism on pancreatic $\beta$ cell function.
\end{abstract}

\section{Keywords}

leucine; glutamate dehydrogenase; mTOR; ATP synthase

\section{Introduction}

\begin{abstract}
Branched-chain amino acids (BCAAs), including leucine, isoleucine and valine, are essential amino acids that cannot be manufactured in humans or other vertebrates and thus must be supplied in daily diet. BCAAs, in particular leucine, play a critical role in controlling protein synthesis by modulating translation initiation in various cells. Leucine is well known to acutely stimulate insulin secretion from pancreatic $\beta$ cells by serving as both metabolic fuel and allosteric activator of glutamate dehydrogenase (GDH) 1`3. Recent reports indicate that leucine or its transaminated product $\alpha$-ketoisocaproate (KIC) might impact on insulin secretion via a direct inhibition of $\beta$ cell $\mathrm{K}_{\mathrm{ATP}}$ currents 4 . In the past decade, leucine had been demonstrated to activate the mammalian target of rapamycin (mTOR), a serine and threonine protein kinase that regulates protein synthesis and cell metabolism, in pancreatic $\beta$ cells 5. To date, leucine has been proven to stimulate gene transcription and protein synthesis in pancreatic islets or other cell types by both mTORdependent and -independent pathways $6^{-9}$. We have recently shown that long-term
\end{abstract}

\footnotetext{
*Address correspondence to: Dr. Jichun Yang, Department of Physiology and Pathophysiology, Peking University Health Science Center, Beijing 100191, P.R.China. Phone: (86)10-82805613; Fax: (86)10-82801447; yangj@ bjmu.edu.cn.

Declaration of interest. The authors have declared that no conflict of interest exists.
} 
treatment with leucine augments glucose-stimulated insulin secretion in INS-1 cells, rat and human islets by upregulating certain metabolic genes via a rapamycin-insensitive mechanism 10, 11. In vivo, leucine administration acutely elevates circulating insulin in human, rodents, and mammals, and improves glycemic control in $\mathrm{db} / \mathrm{db}$ mice or high-fatdiet-induced diabetic mice $12^{-} 14$. A mixture of leucine, isoleucine, and valine acutely elevates circulating insulin levels and enhances glucose clearance after glucose load in healthy human subjects 13,15 . Increase in dietary leucine intake ameliorates diet-induced obesity, hyperglycemia, and hypercholesterolemia in human subjects and rodents via multiple mechanisms 12,16-18. Leucine administration also increases protein synthesis in muscle, adipose and liver via multiple mechanisms 8,19 . Overall, leucine plays an important role in glucose homeostasis by exerting acute and chronic effects on pancreatic $\beta$ cells, liver, muscle and adipose. In this review, recent findings regarding the effects of leucine on pancreatic $\beta$ function will be briefly summarized and discussed. In particular, the therapeutic potential of some metabolic genes regulated by leucine signaling pathways in treatment of islet dysfunction and type 2 diabetes will also be discussed.

\section{Leucine acutely stimulates insulin secretion from pancreatic $\beta$ cells Leucine or its metabolic intermediates regulates $\mathrm{K}_{\mathrm{ATP}}$ channel activity-} Leucine stimulates insulin secretion from pancreatic $\beta$ cells via two main mechanisms. One is in the direction of deamination to yield KIC 20, and the other is to enhance glutaminolysis by allosterically activating glutamate dehydrogenase (GDH), a key enzyme controlling the oxidation of glutamate 21. In the first case, it is believed that leucine or KIC regulates $\mathrm{K}_{\mathrm{ATP}}$ channel activity 4 and results in increase of free cytosolic $\mathrm{Ca}^{2+}$, which then triggers insulin secretory granules exocytosis via mechanisms involving activation of some protein kinases and protein acylation 22,23 . Leucine has been shown to be a more potent insulin secretagogue than its non-metabolic analog, 2-aminobicyclo(2,2,1)heptane-2-carboxylic acid $(\mathrm{BCH}) 24$. Interruption of pyruvate cycling inhibits insulin secretion stimulated by leucine in the presence of glutamine in rat islets and INS-1 cells 25 . Controversially, it has also been reported that KIC may more potently stimulate insulin secretion from islet $\beta$ cells than leucine at the equal molar concentration 26, 27. Recently, we found that leucine and KIC show distinct effects on stimulation of insulin secretion from pancreatic islet cells. We observed that glucose completely blocks the effects of leucine, but not those of KIC on stimulation of insulin secretion from islet $\beta$ cells 20. Branstrom and colleagues demonstrate that KIC closes ATP-sensitive $\mathrm{K}^{+}$channel and induces the depolarization of plasma membrane of $\mathrm{db} / \mathrm{db}$ mouse islet cells via a direct action, whereas leucine fails to do so4. In addition, there is a subset of leucine-sensitive hyperinsulinemic-hypoglycemic children who have mutations in the sulfonylurea receptor 1 (SUR1) subunit of $\mathrm{K}_{\text {ATP }}$ channel but have no mutations in GDH 28, 29. Moreover, a recent study indicates that glutaminolysis stimulated by BCH is enhanced in SUR1 knockout and glyburide-treated wild type islets 30 .

Controversially, Ball and colleagues report that long-term treatment with $100 \mu \mathrm{M}$ glyburide, a potent inhibitor of SUR1, significantly inhibits leucine-stimulated, but not glucosestimulated insulin secretion in BRIN-BD11 cell line 31. Rabaglia and colleagues demonstrate that methyl-leucine or aminooxyacetate, inhibitors of branched-chain amino transferase, blocks KIC-stimulated insulin secretion in diabetes-susceptible BTBR mouse islets 32, suggesting that conversion to leucine plays an important role in KIC-stimulated insulin secretion 20. However, it should be noted that further oxidation of KIC to yield ATP may also play important roles in leucine- or KIC-stimulated insulin secretion 20. We have previously demonstrated that glucose and KIC cause a significant increase in unesterified arachidonic acid accumulation in pancreatic islet cells, whereas mannose, fructose and glyceraldehyde have no significant effects on cellular unesterified arachidonic acid accumulation concomitant with their failure to stimulate insulin secretion 33. Consistent 
with these observations, diabetic Goto-Kakizaki (GK) rat islets have a deficient insulin response to leucine, which has been proposed to be due to decreased generation of acetylCoA from KIC oxidation 34. Recently, MacDonald and colleagues reported that KIC alone fails to stimulate insulin secretion in cultured rat islets and INS-1 832/13 cells 35, 36 .

Allosteric activation of GDH by leucine-There are two GDH isoenzymes in human tissues. One is encoded by GLUD1 gene with ubiquitous expression (housekeeping gene), and the other is encoded by GLUD2 gene with specific expression in neural tissues 37. GDH isotype in pancreatic $\beta$ cells is encoded by GLUD1 gene. GDH is the key enzyme controlling amino acids and ammonia metabolism in pancreatic $\beta$ cells, liver, and brain 38 . Mature human GLUD1-derived GDH without the leader peptide (55 amino acids) contains 505 amino acid residues 39, which form one catalytic domain at the N-terminus and one allosteric domain at the C-terminus 39. Leucine and ADP potently activate GDH, whereas valine, isoleucine and methionine activate GDH weakly. GDH is normally allosterically inhibited by GTP and ATP. It had been reported decades ago that a non-metabolic analog of leucine, $\mathrm{BCH}$, significantly stimulates insulin secretion from pancreatic $\beta$ cells 2,40 . Selective activation of GDH is the main or the only mechanism by which BCH stimulates insulin secretion from $\beta$ cells because it cannot be metabolized 2, 40. Selective inhibition of GDH activity by polyphenols extracted from green tea or 5'-deoxypyridoxal inhibits BCHor leucine-stimulated, but not glucose-stimulated insulin secretion from pancreatic islet cells 41 , 42. Interruption of pyruvate cycling inhibits $\mathrm{BCH}$-stimulated insulin secretion in the presence of glutamine in rat islets and INS-1 cells 25 . Aluminum has also been shown to inhibit human GDH activity by inducing conformational change of the protein 43 . $\mathrm{BCH}$ and other non-metabolic analogs of leucine are very useful to study the acute effects of leucine on stimulation of insulin secretion involving selective activation of GDH in pancreatic $\beta$ cells. We have previously demonstrated that leucine-mediated glutaminolysis via GDH activation may play a critical role in interprandial insulin release when blood glucose falls below $5 \mathrm{mM}$. This basal insulin release accounts for about half of the daily required insulin secretion from $\beta$ cells 44 . Overexpression of GDH significantly enhances insulin secretion by glutamine stimulation alone (2.7 folds) or glutamine plus $\mathrm{BCH}$ (about 6 folds) in pancreatic beta cells. Interestingly, although insulin secretion at low glucose is not affected by GDH overexpression, high glucose-stimulated insulin secretion is significantly potentiated by GDH overexpression in rat islets 45. Consistently, deletion of GDH partially abolishes glucose-stimulated insulin secretion in pancreatic $\beta$ cells 46 . These observations suggest that GDH may also function as a rate-limiting enzyme in the process of glucoseinduced insulin secretion in pancreatic $\beta$ cells beyond its well-established role as a glutamate sensor 45.

Hyperinsulinemia is the most common cause of persistent hypoglycemia in infants and children. Recent discoveries show that the disorders of $\mathrm{K}_{\mathrm{ATP}}$ channel, gain-of-function mutations in glucokinase (GK) and GDH are associated with hyperinsulinemic hypoglycemia of infancy (HHI) 47-49. In 1998, Stanley and colleagues first demonstrated that hyperinsulinism-hyperammonemia syndrome is caused by mutations in the glutamate dehydrogenase gene 39. The authors identified five mutations in glutamate dehydrogenase, which are His454Tyr, Ser445Leu, Gly446Ser, Gly446Asp and Ser448Pro, respectively, from eight patients with hyperinsulinism-hyperammonemia syndrome. Sequence comparison reveals that all these mutations are located in a narrow region near the GTPbinding domain of GDH 39. These mutant GDH proteins show a similar basal enzyme activity and sensitivity to ADP activation, whereas they are insensitive to GTP inhibition as compared with wild type GDH protein. Clearly, the activity of these mutant GDHs may increase in response to amino acid stimulation. Actually, hypoglycemia of hyperinsulinismhyperammonemia syndrome patients will be precipitated after a protein meal or amino acids load 39, 50, 51. Transgenic (TG) mice specifically expressing human His454Tyr GDH in 
pancreatic islet driven by the rat insulin promoter show hypoglycemia as compared with control mice expressing wild type human GDH in islets. In vitro, His454Tyr TG mouse islets secrete more insulin in response to leucine or amino acid mixture in the presence of 2 $\mathrm{mM}$ glutamine than control mouse islets due to increased glutamine oxidation 52. In contrast, glucose-stimulated insulin secretion is inhibited in His454Tyr TG mouse islets when compared with control islets 52. Moreover, although mutation of Arg 443 in regulatory domain of human GDH to Ser significantly impairs its basal enzyme activity, leucine at the concentrations of $0.3 \sim 6.0 \mathrm{mM}$ activates the mutant enzyme activity up to 20 fold in the presence of $0.025 \sim 0.1 \mathrm{mM}$ ADP 53. Recently, Kapoor and colleagues identified another 3 mutations in GDH, which are N410D, D451V and P436L, respectively 54. Interestingly, although P436L GDH is associated with loss of GTP inhibition like other mutants $39,50,51$, the patients with heterozygous P436L GDH have hyperinsulinism and normal serum ammonia concentration54. All these research indicate that GDH plays a crucial role in regulating insulin secretion from pancreatic $\beta$ cells in response to glutamine, leucine, glucose or other fuels. Activating mutations of GDH are predominantly associated with hyperinsulinism-hyperammonemia syndrome. Discoveries and development of selective inhibitors of GDH have shed new light on the treatment of hyperinsulinismhypoglycemia syndrome involving gain-of-function mutations in GDH gene 41 , 55 . In islet $\beta$ cells of $\mathrm{db} / \mathrm{db}$ mice, KIC fails to elevate cellular NADH and $\mathrm{Ca}^{2+}$, whereas glucose potently increases both of them 56. On the contrary, KIC induces hypersecretion of insulin in islets of insulin resistant BTBR mice 32. These observations suggest that dysregulation of leucine-metabolic-linked insulin secretion may be involved in the progression of islet $\beta$ cell dysfunction and type 2 diabetes. In isolated perfused chicken pancreas, 20 and $40 \mathrm{mM} \mathrm{L-}$ leucine or 10-40 mM KIC alone fails to stimulate insulin secretion, while they evokes a slight biphasic insulin release in the presence of $14 \mathrm{mM}$ glucose, suggesting that leucine may stimulate insulin secretion differently in chicken and mammals 57.

In summary, leucine is likely to exert its acute effects on stimulation of insulin secretion from pancreatic islets through combined mechanisms involving regulation of both ATP production and $\mathrm{K}_{\mathrm{ATP}}$ activity. In the former case, leucine-mediated increase in ATP production is achieved through its metabolic oxidation and allosteric activation of GDH that enhances glutaminolysis

\section{Leucine regulates gene transcription and protein synthesis in pancreatic $\beta$ cells}

mTOR-dependent signaling-Mammalian target of rapamycin (mTOR) is a serine and threonine kinase that regulates protein translation via activation of the 70-kDa ribosomal protein $\mathrm{S} 6$ kinase $\left(\mathrm{p} 70^{\mathrm{S} 6 \mathrm{~K}}\right.$ ) and the eukaryotic translation initiation factor 4E-binding protein-1 (4EBP1) 9, 58. The effect of mTOR on enhancement of protein synthesis can be blocked by rapamycin, a widely used immunosuppressant. Recently, a number of studies have revealed that branched-chain amino acids play an important role in regulation of protein synthesis by activating mTOR in pancreatic $\beta$ cells 5, 7, 9, 58. Leucine and KIC significantly stimulate the phosphorylation of $\mathrm{p} 70^{\mathrm{S} 6 \mathrm{~K}}$ and enhance protein synthesis in pancreatic $\beta$ cells in a rapamycin-sensitive and insulin-independent manner at physiological concentrations ranging from $0.4 \mathrm{mM}$ to $4 \mathrm{mM} 9,58,59$. Similarly, isoleucine and valine also activate $\mathrm{p} 70^{\mathrm{S} 6 \mathrm{~K}}$ in these studies 9, 58, 59. In contrast, $\mathrm{BCH}$ fails to activate mTOR and $\mathrm{p} 70^{\mathrm{S} 6 \mathrm{~K}}$ at the concentrations ranging from $0.2 \mathrm{mM}$ to $10 \mathrm{mM} 58$. These results indicate that leucine activates mTOR signaling pathway by a metabolic-linked mechanism, in which GDH activation is unlikely involved. Protein-energy malnutrition has been reported to inhibit pancreatic $\beta$ cell replication in the fetal rodent pancreas by an unknown mechanism 60 , 61. Since leucine diversely and nonspecifically stimulates protein synthesis in pancreatic $\beta$ cells via mTOR-dependent mechanism, certain important transcriptional regulator(s) might be degraded under low-leucine condition, resulting in consequential inhibition of gene 
transcription and $\beta$ cell replication observed in these studies 60, 61. A recent study reveals that the inhibition of AMPK activity by glucose and amino acids may be involved in nutrient-stimulated mTOR activation but not in insulin secretion in pancreatic $\beta$ cells 62 . Consistently, activation of AMPK by 5-aminoimidazole-4-carboxamide-1-beta-Dribonucleoside (AICAR) inhibits leucine-induced increases in mTOR activity and protein synthesis in rat skeletal muscle under in vivo conditions 63. Importantly, leucine has also been shown to enhance protein synthesis by mTOR-mediated activation of $\mathrm{p} 70^{\mathrm{S} 6 \mathrm{~K}}$ and 4EBP1 in other tissues such as liver, muscle, adipose, and myoblast 6, $64^{-7} 71$.

mTOR-independent signaling-We have recently demonstrated that long-term culture with leucine upregulates certain metabolic genes via an unknown mechanism 10, 11. Rapamycin at the concentration of $10 \mathrm{nM}$ fails to block the induction of these metabolic genes by leucine at $10 \mathrm{mM}$. Rapamycin has been used at the concentration of $10 \mathrm{nM}$ in these studies 10, 11 because long-term treatment with rapamycin greater than $10 \mathrm{nM}$ significantly induces apoptosis of pancreatic $\beta$ cells 72 . Although the rapamycin concentration tested in our studies is lower than that in other studies 9, 58, in which the acute effects of leucine on mTOR activation have been evaluated, we still cannot rule out the possibility that leucine regulates gene expression or protein synthesis via a rapamycin-insensitive signaling pathway in pancreatic islet cells. In support, Talvas and colleagues report that there is a lack of regulation of mTOR activity in response to leucine deprivation in $\mathrm{C} 2 \mathrm{C} 12$ myotubes, suggesting that the activation of $\mathrm{p} 70^{\mathrm{S} 6 \mathrm{~K}}$ may be achieved through an mTOR-independent mechanism. The authors further show that the availability of eIF4E with eIF2 $\alpha$ phosphorylation is not determinant for decreasing global protein synthesis in leucine deprivation condition 73. As extensively reviewed and discussed in reference 88 , rapamycin attenuates but does not prevent the leucine-induced enhancement of protein synthesis or eIF4F complex formation. It has been proposed that leucine regulates muscle protein synthesis through both an insulin- and mTOR-dependent signaling pathway involving 4EBP1 and $\mathrm{p} 70^{\mathrm{S} 6 \mathrm{~K}}$ phosphorylation, and an insulin- and mTOR-independent pathway involving enhanced eIF4F complex formation 8 . In addition, Blomstrand and colleagues also report that branched-chain amino acids, in particular leucine, can stimulate phosphorylation of $\mathrm{p} 70^{\mathrm{S} 6 \mathrm{~K}}$ and enhance protein synthesis in muscle by a mechanism involving both mTORdependent and -independent pathways 6 . Lee and colleagues report that leucine increases ${ }^{3} \mathrm{H}$-thymidine incorporation and cell proliferation in chicken hepatocytes through a mechanism involving both PKC/ERK1/2 signaling pathway and mTOR-dependent signaling pathway 74 . Rapamycin fails to block swelling-independent proteolysis inhibition by leucine in perfused rat livers, suggesting that at least rapamycin-sensitive mTOR activation is not involved in this process 75 . Islets isolated from mice fed on a low protein (LP) diet for 8 weeks have lower expression levels of insulin receptor substrate-1 (IRS-1) and $\mathrm{p} 70^{\mathrm{S} 6 \mathrm{~K}}$ than those from mice fed on normal protein (NP) diet. Glucose- and leucine-stimulated insulin secretion are significantly impaired in islets of LP-diet-fed mice when compared with control islets 76 . Overall, it is likely that leucine also regulate gene transcription and protein synthesis in pancreatic $\beta$ cells by mTOR-independent signaling pathway(s).

\section{Leucine regulation reveals that ATP synthase functions as a rate-limiting enzyme in the process of insulin secretion}

Given the well-established facts that leucine nonspecifically enhances protein synthesis via mTOR-dependent and/or -independent mechanisms, it is reasonable to speculate that the protein expression of some transcription regulators or important metabolic enzymes might be upregulated by long-term treatment of leucine in pancreatic $\beta$ cells. Thus, leucine may exert a long-term impact on insulin secretion and cell function of pancreatic $\beta$ cells by regulating gene expression. To test this hypothesis, a genome-wide screening of 40,000 genes in RINm5F cells treated with leucine using microarray analysis has been performed 
by our laboratory. The microarray analysis results show that treatment with $10 \mathrm{mM}$ leucine for 24 hours up-regulates ATP synthase $\beta$ subunit (ATP $\beta$ ) mRNA level by 3.2 fold. In contrast, the expression of other subunits of mitochondrial ATP synthase complex is not affected by leucine treatment 10,11 . The effect of long-term treatment with leucine on upregulation of ATP $\beta$ mRNA and protein levels is further confirmed in rat islets, INS- 1 cells and human islets. Leucine regulation, siRNA knockdown and plasmid overexpression experiments indicate that ATP synthase (ATP $\beta$ ) may function as a rate-limiting enzyme in the process of insulin secretion upon GK activation 10, 11, which is consistent with the previous observations that overexpression of GK alone fails to augment insulin secretion in INS-1 cells 77, 78. However, it should be noted that the enhancement of insulin secretion in rat and human islets by long-term leucine treatment in our studies is likely due to the change of a bunch of metabolic genes including ATP $\beta$ 11. Consistently, mitochondria has been reported to set the limit of fuel-induced insulin secretion in pancreatic islets 79. Our findings contradict a previous report that 24 -h culture with $20 \mathrm{mM}$ leucine impairs glucose-induced insulin secretion and increases ADP level in rat islets. However, the lack of changes in the ATP level and glucose utilization and oxidation in this study is difficult to explain 80 . Moreover, Zhang and colleagues report that chronic exposure to leucine downregulates the expression of PDX-1, GK, and GLUT2 in rat insulinoma beta-cells, resulting in decreased insulin content and glucose-induced insulin secretion at high glucose 81. Martens and colleagues demonstrate that treatment with $10 \mathrm{mM}$ leucine for 72 hours significantly reduces apoptosis of rat islet $\beta$ cells concomitant with decreased reactive oxygen species (ROS) levels 82. Given that all of the catalytic sites of F1 ATP synthase are located either exclusively on the $\beta$ subunits or at interfaces between $\beta$ and $\alpha$ subunits (ATP $\alpha$ ) 83,84 , reduced expression of ATP $\beta$ or ATP $\alpha$ will definitely impair ATP synthesis in mitochondria. It has been reported that reduced cellular ATP content are associated with decreased expression of ATP $\beta$ or ATP $\alpha$ in various tissues of diabetic human and rodents 85,86 . Recently, ATP $\beta$ is shown to be expressed in the plasma membrane of various cell types and a putative receptor for enterostatin, a pentapeptide secreted by stomach and pancreas 87,88 . Incubation with enterostatin for 60 minutes significantly stimulates the translocation of ATP $\beta$ to the plasma membrane of INS- 1 cells by 3.5 fold 89 , which may have reduced mitochondrial ATP $\beta$ content and thus impaired ATP synthesis. This observation may partially explain the previous observations that enterostatin inhibits fuel-stimulated insulin secretion from pancreatic $\beta$ cells $90^{-} 92$. Chronic exposure to free fatty acids (FFAs) also stimulates the translocation of ATP $\beta$ to the plasma membrane of INS- 1 cells 89 , which may also contribute to the deleterious effects of FFAs on pancreatic $\beta$ cells 93 .

Pancreatic $\beta$ cell dysfunction is a decisive cause of type 2 diabetes. Obesity-related hyperglycemia, hyperlipidemia and excessive circulating inflammatory cytokines are the most important physiological factors causing $\beta$ cell dysfunction. In the past decade, increasing evidence had suggested that inhibition of ATP synthesis in mitochondria is the central event during the progression of $\beta$ cell dysfunction (Figure 1). Long-term lipid or glycemic stress activates uncoupling protein 2 (UCP2) expression in islet $\beta$ cells, which initially prevents cells from being damaged by lipotoxic or glucotoxic insult by decreasing the proton potential $(\Delta \psi)$ between intermembrane space and inner membrane of the mitochondria 94, 95. However, mitochondrial ATP synthesis and insulin secretion from pancreatic islet $\beta$ cells will be inhibited by an increase in UCP2 expression 96, 97. Genipin, a UCP2 inhibitor, acutely reverses obesity- and high glucose-induced $\beta$ cell dysfunction in isolated pancreatic islets 97 . Köhnke and colleagues report that a combination of fatty acids and glucose at high concentration downregulates ATP $\beta$ expression in INS- 1 cells and reduces cellular ATP content. The authors further propose that the decrease in ATP synthesis rate in mitochondria resulting from downregulation of ATP $\beta$ plays a crucial role in fatty acid- and glucose-induced $\beta$ cell dysfunction 98 . Other alternative mechanisms through which fatty acids induce pancreatic $\beta$ cell dysfunction and apoptosis include activation of 
PERK and microRNAs, oxidative stress, and excessive accumulation of cellular ceramide 99, 100. Chronic exposure to excessive proinflammatory cytokines including IL-1 $\beta$, TNF- $\alpha$ and INF- $\gamma$ activates inducible nitrogen synthase (iNOS) in pancreatic islet $\beta$ cells, which produces excessive NO. NO binds to Complex IV of mitochondrial respiratory chain and inhibits the formation of proton gradient in pancreatic $\beta$ cell mitochondria. Thus, inhibition of ATP synthesis is likely to be involved in cytokine-induced pancreatic $\beta$ cell dysfunction and apoptosis 101, 102. Chronic exposure of islet $\beta$ cells to high glucose will both upregulate GK gene expression and allosterically activate GK activity, resulting in sequential increases in glucose oxidation, electron transport rate in electron transport chain (ETC) and mitochondrial $\Delta \psi 103,104$. It has been reported that high mitochondrial $\Delta \psi$ is the primary cause of excessive production of ROS in pancreatic $\beta$ cells under hyperglycemic and hyperlipidemic conditions 105 , 106 . Consistently, although glucose oxidation is increased, cellular ATP content under glucose stimulation is significantly reduced in $\beta$ cell lines overexpressing GK. Moreover, GK overexpressing cells produce more ROS concomitant with increased apoptotic cells under the stimulation of high glucose 107. In contrast, PPAR- $\gamma$ agonists have been shown to protect $\beta$ cells from fatty acid-induced oxidative stress and cell apoptosis by increasing cellular ATP content and decreasing ROS levels 108. Similarly, transgenic mice specifically overexpressing GK in liver show impaired glucose tolerance over 6 months old 109. These results indicate that long-term activation of GK alone enhances glucose oxidation and elevates mitochondrial $\Delta \psi$, which results in excessive ROS production. To increase the mitochondrial proton leak rate, either by ATP synthesis 10,11, 82 or UCP2-mediated heat production 106, 110, will be important for maintaining normal mitochondrial $\Delta \psi$ and preventing excessive ROS production in pancreatic islet $\beta$ cells under hyperglycemic and hyperlipidemic conditions (Figure 1). Clearly, leucine may also attenuate glucotoxicity by inhibition of ROS production via increase in ATP synthesis10, 11 or other unknown mechanisms82.

To date, the mechanism by which leucine upregulates GK and ATP $\beta$ still remains unknown. However, recent studies have suggested that leucine signaling pathway may have crosstalk with some transcriptors or nuclear receptors including PDX-1111, LXR 112 and PPAR $\gamma 113^{-} 115$ in upregulation of GK and ATP $\beta$.

Overall, the decrease in mitochondrial ATP synthesis rate is associated with the progression of pancreatic islet dysfunction and type 2 diabetes. To elevate cellular ATP synthesis rate by leucine-mediated upregulation of ATP $\beta$ or other metabolic enzymes may represent a potential intervention strategy for treatment of islet dysfunction and type 2 diabetes.

\section{Conclusion and perspective}

Leucine plays important roles in regulation of insulin secretion and cell metabolism of pancreatic $\beta$ cells via acute and chronic effects (Figure 2). Allosteric regulation of GDH activity by leucine and/or other molecules has been demonstrated to be a potential intervention strategy for some insulin secretion disorders. In addition, further studies on the distinct mechanism(s) by which leucine regulates the expression of key metabolic genes in pancreatic $\beta$ cells will shed new light on prevention and treatment of islet dysfunction and type 2 diabetes.

\section{Acknowledgments}

Funding. This work was supported by grants from the Natural Science Foundation of China (NSFC 30870995 and 30771030 to J.Y), Program from the Ministry of Education of China "New Century Excellent Talents in Universities" (to J.Y), and National Institute of Diabetes, Digestive, and Kidney Diseases (DK070744 to B.R.B). We also thank Pro. Yuansheng Gao, Drs. Jihong Kang and Robert A, Young for critical comments during manuscript preparation. 


\section{References}

1. Stanley CA. Hyperinsulinism/hyperammonemia syndrome: insights into the regulatory role of glutamate dehydrogenase in ammonia metabolism. Mol Genet Metab. 2004; 81(Suppl 1):45-51. [PubMed: 14728990]

2. Sener A, Malaisse WJ. L-leucine and a nonmetabolized analogue activate pancreatic islet glutamate dehydrogenase. Nature. 1980; 288:187-189. [PubMed: 7001252]

3. Liu YJ, Cheng H, Drought H, MacDonald MJ, Sharp GW, Straub SG. Activation of the KATP channel-independent signaling pathway by the nonhydrolyzable analog of leucine, BCH. Am J Physiol Endocrinol Metab. 2003; 285:380-389.

4. Branstrom R, Efendic S, Berggren PO, Larsson O. Direct inhibition of the pancreatic beta-cell ATPregulated potassium channel by alpha-ketoisocaproate. J Biol Chem. 1998; 273:14113-14118. [PubMed: 9603910]

5. McDaniel ML, Marshall CA, Pappan KL, Kwon G. Metabolic and autocrine regulation of the mammalian target of rapamycin by pancreatic beta-cells. Diabetes. 2002; 51:2877-2885. [PubMed: 12351422]

6. Blomstrand E, Eliasson J, Karlsson HK, Kohnke R. Branched-chain amino acids activate key enzymes in protein synthesis after physical exercise. J Nutr. 2006; 136(1 Suppl):269S-273S. [PubMed: 16365096]

7. Stipanuk MH. Leucine and protein synthesis: mTOR and beyond. Nutr Rev. 2007; 65:122-129. [PubMed: 17425063]

8. Yoshizawa F. Regulation of protein synthesis by branched-chain amino acids in vivo. Biochem Biophys Res Commun. 2004; 313:417-422. [PubMed: 14684178]

9. Kwon G, Marshall CA, Pappan KL, Remedi MS, McDaniel ML. Signaling elements involved in the metabolic regulation of mTOR by nutrients, incretins, and growth factors in islets. Diabetes. 2004; 53(Suppl 3):S225-232. [PubMed: 15561916]

10. Yang J, Wong RK, Wang X, et al. Leucine culture reveals that ATP synthase functions as a fuel sensor in pancreatic beta-cells. J Biol Chem. 2004; 279:53915-53923. [PubMed: 15489222]

11. Yang J, Wong RK, Park M, et al. Leucine regulation of glucokinase and ATP synthase sensitizes glucose-induced insulin secretion in pancreatic beta-cells. Diabetes. 2006; 55:193-201. [PubMed: 16380493]

12. Zhang Y, Guo K, LeBlanc RE, Loh D, Schwartz GJ, Yu YH. Increasing dietary leucine intake reduces diet-induced obesity and improves glucose and cholesterol metabolism in mice via multimechanisms. Diabetes. 2007; 56:1647-1654. [PubMed: 17360978]

13. Nilsson M, Holst JJ, Bjorck IM. Metabolic effects of amino acid mixtures and whey protein in healthy subjects: studies using glucose-equivalent drinks. Am J Clin Nutr. 2007; 85:996-1004. [PubMed: 17413098]

14. Rozance PJ, Limesand SW, Hay WW Jr. Decreased nutrient-stimulated insulin secretion in chronically hypoglycemic late-gestation fetal sheep is due to an intrinsic islet defect. Am J Physiol Endocrinol Metab. 2006; 291:404-411.

15. Kalogeropoulou D, Lafave L, Schweim K, Gannon MC, Nuttall FQ. Leucine, when ingested with glucose, synergistically stimulates insulin secretion and lowers blood glucose. Metabolism. 2008; 57:1747-1752. [PubMed: 19013300]

16. Parker B, Noakes M, Luscombe N, Clifton P. Effect of a high-protein, high-monounsaturated fat weight loss diet on glycemic control and lipid levels in type 2 diabetes. Diabetes Care. 2002; 25:425-430. [PubMed: 11874925]

17. Baum JI, Layman DK, Freund GG, Rahn KA, Nakamura MT, Yudell BE. A reduced carbohydrate, increased protein diet stabilizes glycemic control and minimizes adipose tissue glucose disposal in rats. J Nutr. 2006; 136:1855-1861. [PubMed: 16772449]

18. Layman DK, Walker DA. Potential importance of leucine in treatment of obesity and the metabolic syndrome. J Nutr. 2006; 136(1 Suppl):319S-323S. [PubMed: 16365106]

19. Combaret L, Dardevet D, Rieu I, et al. A leucine-supplemented diet restores the defective postprandial inhibition of proteasome-dependent proteolysis in aged rat skeletal muscle. J Physiol. 2005; 569:489-499. [PubMed: 16195315] 
20. Gao Z, Young RA, Li G, et al. Distinguishing features of leucine and alpha-ketoisocaproate sensing in pancreatic beta-cells. Endocrinology. 2003; 144:1949-1957. [PubMed: 12697702]

21. Smith TJ, Stanley CA. Untangling the glutamate dehydrogenase allosteric nightmare. Trends Biochem Sci. 2008; 33:557-64. [PubMed: 18819805]

22. Henquin JC, Gembal M, Detimary P, Gao ZY, Warnotte C, Gilon P. Multisite control of insulin release by glucose. Diabete Metab. 1994; 20:132-137. [PubMed: 7805950]

23. Straub SG, Sharp GW. Inhibition of insulin secretion by cerulenin might be due to impaired glucose metabolism. Diabetes Metab Res Rev. 2007; 23:146-151. [PubMed: 16705622]

24. Macdonald MJ, Hasan NM, Longacre MJ. Studies with leucine, beta-hydroxybutyrate and ATP citrate lyase-deficient beta cells support the acetoacetate pathway of insulin secretion. Biochim Biophys Acta. 2008; 1780:966-972. [PubMed: 18439432]

25. Pongratz RL, Kibbey RG, Shulman GI, Cline GW. Cytosolic and mitochondrial malic enzyme isoforms differentially control insulin secretion. J Biol Chem. 2007; 282:200-207. [PubMed: 17102138]

26. Malaisse-Lagae F, Sener A, Garcia-Morales P, Valverde I, Malaisse WJ. The stimulus-secretion coupling of amino acid-induced insulin release. Influence of a nonmetabolized analog of leucine on the metabolism of glutamine in pancreatic islets. J Biol Chem. 1982; 257:3754-3758. [PubMed: 7037786]

27. Lenzen S, Formanek H, Panten U. Signal function of metabolism of neutral amino acids and 2-keto acids for initiation of insulin secretion. J Biol Chem. 1982; 257:6631-6633. [PubMed: 7045091]

28. Magge SN, Shyng SL, MacMullen C, et al. Familial leucine-sensitive hypoglycemia of infancy due to a dominant mutation of the beta-cell sulfonylurea receptor. J Clin Endocrinol Metab. 2004; 89:4450-4456. [PubMed: 15356046]

29. Kelly A, Ng D, Ferry RJ Jr. et al. Acute insulin responses to leucine in children with the hyperinsulinism/hyperammonemia syndrome. J Clin Endocrinol Metab. 2001; 86:3724-3728. [PubMed: 11502802]

30. Li C, Nissim I, Chen P, et al. Elimination of KATP channels in mouse islets results in elevated [U-13C]glucose metabolism, glutaminolysis, and pyruvate cycling but a decreased gammaaminobutyric acid shunt. J Biol Chem. 2008; 283:17238-17249. [PubMed: 18445600]

31. Ball AJ, Flatt PR, McClenaghan NH. Acute and long-term effects of nateglinide on insulin secretory pathways. Br J Pharmacol. 2004; 142:367-373. [PubMed: 15155541]

32. Rabaglia ME, Gray-Keller MP, Frey BL, Shortreed MR, Smith LM, Attie AD. AlphaKetoisocaproate-induced hypersecretion of insulin by islets from diabetes-susceptible mice. Am J Physiol Endocrinol Metab. 2005; 289:E218-224. [PubMed: 15741243]

33. Konrad RJ, Jolly YC, Major C, Wolf BA. Fuel secretagogue stimulation of arachidonic acid accumulation in fresh and cultured pancreatic islets. Mol Cell Endocrinol. 1993; 92:135-140. [PubMed: 8472864]

34. Giroix MH, Saulnier C, Portha B. Decreased pancreatic islet response to L-leucine in the spontaneously diabetic GK rat: enzymatic, metabolic and secretory data. Diabetologia. 1999; 42:965-977. [PubMed: 10491757]

35. MacDonald MJ. Synergistic potent insulin release by combinations of weak secretagogues in pancreatic islets and INS-1 cells. J Biol Chem. 2007; 282:6043-6052. [PubMed: 17210580]

36. MacDonald MJ, Stoker SW, Hasan NM. Anaplerosis from glucose, alpha-ketoisocaproate, and pyruvate in pancreatic islets, INS-1 cells and liver mitochondria. Mol Cell Biochem. 2008; 313:195-202. [PubMed: 18414997]

37. Plaitakis A, Metaxari M, Shashidharan P. Nerve tissue-specific (GLUD2) and housekeeping (GLUD1) human glutamate dehydrogenases are regulated by distinct allosteric mechanisms: implications for biologic function. J Neurochem. Nov; 2000 75(5):1862-1869. [PubMed: 11032875]

38. De Leon DD, Stanley CA. Mechanisms of Disease: advances in diagnosis and treatment of hyperinsulinism in neonates. Nat Clin Pract Endocrinol Metab. Jan; 2007 3(1):57-68. [PubMed: 17179930] 
39. Stanley CA, Lieu YK, Hsu BY, et al. Hyperinsulinism and hyperammonemia in infants with regulatory mutations of the glutamate dehydrogenase gene. N Engl J Med. May 7; 1998 338(19): 1352-1357. [PubMed: 9571255]

40. Gylfe E. Comparison of the effects of leucines, non-metabolizable leucine analogues and other insulin secretagogues on the activity of glutamate dehydrogenase. Acta Diabetol Lat. Jan-Apr; 1976 13(1-2):20-24. [PubMed: 987682]

41. Li C, Allen A, Kwagh J, et al. Green tea polyphenols modulate insulin secretion by inhibiting glutamate dehydrogenase. J Biol Chem. 2006; 281:10214-10221. [PubMed: 16476731]

42. Yang SJ, Huh JW, Kim MJ, et al. Regulatory effects of 5'-deoxypyridoxal on glutamate dehydrogenase activity and insulin secretion in pancreatic islets. Biochimie. 2003; 85:581-586. [PubMed: 12829375]

43. Yang SJ, Huh JW, Lee JE, Choi SY, Kim TU, Cho SW. Inactivation of human glutamate dehydrogenase by aluminum. Cell Mol Life Sci. 2003; 60:2538-2546. [PubMed: 14625697]

44. Gao ZY, Li G, Najafi H, Wolf BA, Matschinsky FM. Glucose regulation of glutaminolysis and its role in insulin secretion. Diabetes. 1999; 48:1535-1542. [PubMed: 10426370]

45. Carobbio S, Ishihara H, Fernandez-Pascual S, Bartley C, Martin-Del-Rio R, Maechler P. Insulin secretion profiles are modified by overexpression of glutamate dehydrogenase in pancreatic islets. Diabetologia. 2004; 47:266-276. [PubMed: 14689183]

46. Carobbio S, Frigerio F, Rubi B, et al. Deletion of glutamate dehydrogenase in beta-cells abolishes part of the insulin secretory response not required for glucose homeostasis. J Biol Chem. 2008; 284:921-929. [PubMed: 19015267]

47. Dekelbab BH, Sperling MA. Hyperinsulinemic hypoglycemia of infancy: the challenge continues. Diabetes Metab Res Rev. 2004; 20:189-195. [PubMed: 15133749]

48. Dekelbab BH, Sperling MA. Hypoglycemia in newborns and infants. Adv Pediatr. 2006; 53:5-22. [PubMed: 17089861]

49. Dekelbab BH, Sperling MA. Recent advances in hyperinsulinemic hypoglycemia of infancy. Acta Paediatr. 2006; 95:1157-1164. [PubMed: 16982483]

50. Hsu BY, Kelly A, Thornton PS, Greenberg CR, Dilling LA, Stanley CA. Protein-sensitive and fasting hypoglycemia in children with the hyperinsulinism/hyperammonemia syndrome. J Pediatr. 2001; 138:383-389. [PubMed: 11241047]

51. MacMullen C, Fang J, Hsu BY, et al. Hyperinsulinism/hyperammonemia syndrome in children with regulatory mutations in the inhibitory guanosine triphosphate-binding domain of glutamate dehydrogenase. J Clin Endocrinol Metab. 2001; 86:1782-1787. [PubMed: 11297618]

52. Li C, Matter A, Kelly A, et al. Effects of a GTP-insensitive mutation of glutamate dehydrogenase on insulin secretion in transgenic mice. J Biol Chem. 2006; 281:15064-15072. [PubMed: 16574664]

53. Zaganas I, Spanaki C, Karpusas M, Plaitakis A. Substitution of Ser for Arg-443 in the regulatory domain of human housekeeping (GLUD1) glutamate dehydrogenase virtually abolishes basal activity and markedly alters the activation of the enzyme by ADP and L-leucine. J Biol Chem. 2002; 277:46552-46558. [PubMed: 12324473]

54. Kapoor R, Flanagan S, Fulton P, et al. Hyperinsulinism-hyperammonaemia (HI/HA) syndrome: novel mutations in the GLUD1 gene and genotype-phenotype correlations. Eur J Endocrinol. Aug 18.2009

55. Li M, Allen A, Smith TJ. High throughput screening reveals several new classes of glutamate dehydrogenase inhibitors. Biochemistry. 2007; 46:15089-15102. [PubMed: 18044977]

56. Gustavsson N, Larsson-Nyren G, Lindstrom P. Pancreatic beta cells from db/db mice show cellspecific [Ca2+]i and NADH responses to glucose but not to alpha-ketoisocaproic acid. Pancreas. 2005; 31:242-250. [PubMed: 16163056]

57. Rideau N, Simon J. L-leucine or its keto acid potentiate but do not initiate insulin release in chicken. Am J Physiol. 1989; 257:15-19.

58. Xu G, Kwon G, Cruz WS, Marshall CA, McDaniel ML. Metabolic regulation by leucine of translation initiation through the mTOR-signaling pathway by pancreatic beta-cells. Diabetes. 2001; 50:353-360. [PubMed: 11272147] 
59. Xu G, Kwon G, Marshall CA, Lin TA, Lawrence JC Jr. McDaniel ML. Branched-chain amino acids are essential in the regulation of PHAS-I and p70 S6 kinase by pancreatic beta-cells. A possible role in protein translation and mitogenic signaling. J Biol Chem. 1998; 273:28178-28184. [PubMed: 9774438]

60. Swenne I. Pancreatic beta-cell growth and diabetes mellitus. Diabetologia. 1992; 35:193-201. [PubMed: 1563578]

61. Swenne I, Borg LA, Crace CJ, Schnell Landstrom A. Persistent reduction of pancreatic beta-cell mass after a limited period of protein-energy malnutrition in the young rat. Diabetologia. 1992; 35:939-945. [PubMed: 1451950]

62. Gleason CE, Lu D, Witters LA, Newgard CB, Birnbaum MJ. The role of AMPK and mTOR in nutrient sensing in pancreatic beta-cells. J Biol Chem. 2007; 282:10341-10351. [PubMed: 17287212]

63. Pruznak AM, Kazi AA, Frost RA, Vary TC, Lang CH. Activation of AMP-activated protein kinase by 5-aminoimidazole-4-carboxamide-1-beta-D-ribonucleoside prevents leucine-stimulated protein synthesis in rat skeletal muscle. J Nutr. 2008; 138:1887-1894. [PubMed: 18806097]

64. Fox HL, Kimball SR, Jefferson LS, Lynch CJ. Amino acids stimulate phosphorylation of p70S6k and organization of rat adipocytes into multicellular clusters. Am J Physiol. 1998; 274:206-213.

65. Kimball SR, Horetsky RL, Jefferson LS. Implication of eIF2B rather than eIF4E in the regulation of global protein synthesis by amino acids in L6 myoblasts. J Biol Chem. 1998; 273:30945-30953. [PubMed: 9812990]

66. Lynch CJ, Fox HL, Vary TC, Jefferson LS, Kimball SR. Regulation of amino acid-sensitive TOR signaling by leucine analogues in adipocytes. J Cell Biochem. 2000; 77:234-251. [PubMed: 10723090]

67. Pham PT, Heydrick SJ, Fox HL, Kimball SR, Jefferson LS Jr. Lynch CJ. Assessment of cellsignaling pathways in the regulation of mammalian target of rapamycin (mTOR) by amino acids in rat adipocytes. J Cell Biochem. 2000; 79:427-441. [PubMed: 10972980]

68. Reiter AK, Anthony TG, Anthony JC, Jefferson LS, Kimball SR. The mTOR signaling pathway mediates control of ribosomal protein mRNA translation in rat liver. Int J Biochem Cell Biol. 2004; 36:2169-2179. [PubMed: 15313464]

69. Evans K, Nasim Z, Brown J, et al. Acidosis-sensing glutamine pump SNAT2 determines amino acid levels and mammalian target of rapamycin signalling to protein synthesis in L6 muscle cells. $\mathrm{J}$ Am Soc Nephrol. 2007; 18:1426-1436. [PubMed: 17429052]

70. Du M, Shen QW, Zhu MJ, Ford SP. Leucine stimulates mammalian target of rapamycin signaling in $\mathrm{C} 2 \mathrm{C} 12$ myoblasts in part through inhibition of adenosine monophosphate-activated protein kinase. J Anim Sci. 2007; 85:919-927. [PubMed: 17178807]

71. Dardevet D, Kimball SR, Jefferson LS, et al. Portal infusion of amino acids is more efficient than peripheral infusion in stimulating liver protein synthesis at the same hepatic amino acid load in dogs. Am J Clin Nutr. 2008; 88:986-996. [PubMed: 18842785]

72. Bell E, Cao X, Moibi JA, et al. Rapamycin has a deleterious effect on MIN-6 cells and rat and human islets. Diabetes. 2003; 52:2731-2739. [PubMed: 14578291]

73. Talvas J, Obled A, Fafournoux P, Mordier S. Regulation of protein synthesis by leucine starvation involves distinct mechanisms in mouse C2C12 myoblasts and myotubes. J Nutr. 2006; 136:14661471. [PubMed: 16702305]

74. Lee MY, Jo SD, Lee JH, Han HJ. L-leucine increases [3H]-thymidine incorporation in chicken hepatocytes: involvement of the PKC, PI3K/Akt, ERK1/2, and mTOR signaling pathways. J Cell Biochem. 2008; 105:1410-1419. [PubMed: 18980246]

75. Schliess F, Richter L, vom Dahl S, Haussinger D. Cell hydration and mTOR-dependent signalling. Acta Physiol (Oxf). 2006; 187:223-229. [PubMed: 16734759]

76. Filiputti E, Ferreira F, Souza KL, et al. Impaired insulin secretion and decreased expression of the nutritionally responsive ribosomal kinase protein S6K-1 in pancreatic islets from malnourished rats. Life Sci. 2008; 82:542-548. [PubMed: 18234235]

77. Wang H, Iynedjian PB. Acute glucose intolerance in insulinoma cells with unbalanced overexpression of glucokinase. J Biol Chem. 1997; 272:25731-25736. [PubMed: 9325299] 
78. Wang H, Iynedjian PB. Modulation of glucose responsiveness of insulinoma beta-cells by graded overexpression of glucokinase. Proc Natl Acad Sci U S A. 1997; 94:4372-4377. [PubMed: 9113996]

79. Antinozzi PA, Ishihara H, Newgard CB, Wollheim CB. Mitochondrial metabolism sets the maximal limit of fuel-stimulated insulin secretion in a model pancreatic beta cell: a survey of four fuel secretagogues. J Biol Chem. 2002; 277:11746-11755. [PubMed: 11821387]

80. Anello M, Ucciardello V, Piro S, et al. Chronic exposure to high leucine impairs glucose-induced insulin release by lowering the ATP-to-ADP ratio. Am J Physiol Endocrinol Metab. 2001; 281:1082-1087.

81. Zhang X, Sun N, Wang L, et al. AMP-activated protein kinase and pancreatic/duodenal homeobox-1 involved in insulin secretion under high leucine exposure in rat insulinoma beta-cells. J Cell Mol Med. 2009; 13:758-770. [PubMed: 19438972]

82. Martens GA, Cai Y, Hinke S, Stange G, Van de Casteele M, Pipeleers D. Glucose suppresses superoxide generation in metabolically responsive pancreatic beta cells. J Biol Chem. 2005; 280:20389-20396. [PubMed: 15774474]

83. Futai M, Noumi T, Maeda M. ATP synthase (H+-ATPase): results by combined biochemical and molecular biological approaches. Annu Rev Biochem. 1989; 58:111-136. [PubMed: 2528322]

84. Mills DA, Richter ML. Nucleotide binding to the isolated beta subunit of the chloroplast ATP synthase. J Biol Chem. 1991; 266:7440-7444. [PubMed: 1826906]

85. Boudina S, Sena S, Theobald H, et al. Mitochondrial energetics in the heart in obesity-related diabetes: direct evidence for increased uncoupled respiration and activation of uncoupling proteins. Diabetes. 2007; 56:2457-2466. [PubMed: 17623815]

86. Hojlund K, Wrzesinski K, Larsen PM, et al. Proteome analysis reveals phosphorylation of ATP synthase beta -subunit in human skeletal muscle and proteins with potential roles in type 2 diabetes. J Biol Chem. 2003; 278:10436-10442. [PubMed: 12531894]

87. Park M, Lin L, Thomas S, et al. The F1-ATPase beta-subunit is the putative enterostatin receptor. Peptides. 2004; 25:2127-2133. [PubMed: 15572201]

88. York DA, Lin L, Thomas SR, Braymer HD, Park M. Procolipase gene expression in the rat brain: source of endogenous enterostatin production in the brain. Brain Res. 2006; 1087:52-59. [PubMed: 16624258]

89. Lindqvist A, Berger K, Erlanson-Albertsson C. Enterostatin up-regulates the expression of the beta-subunit of $\mathrm{F}(1) \mathrm{F}(\mathrm{o})$-ATPase in the plasma membrane of INS-1 cells. Nutr Neurosci. 2008; 11:55-60. [PubMed: 18510804]

90. Silvestre RA, Rodriguez-Gallardo J, Marco J. Effect of enterostatin on insulin, glucagon, and somatostatin secretion in the perfused rat pancreas. Diabetes. 1996; 45:1157-1160. [PubMed: 8772715]

91. Ookuma M, York DA. Inhibition of insulin release by enterostatin. Int J Obes Relat Metab Disord. 1998; 22:800-805. [PubMed: 9725641]

92. Mei J, Bouras M, Erlanson-Albertsson C. Inhibition of insulin release by intraduodenally infused enterostatin-VPDPR in rats. Peptides. 1997; 18:651-655. [PubMed: 9213357]

93. Bergman RN, Ader M. Free fatty acids and pathogenesis of type 2 diabetes mellitus. Trends Endocrinol Metab. 2000; 11:351-356. [PubMed: 11042464]

94. Chan CB, Saleh MC, Koshkin V, Wheeler MB. Uncoupling protein 2 and islet function. Diabetes. 2004; 53(Suppl 1):S136-142. [PubMed: 14749279]

95. Azzu V, Affourtit C, Breen EP, Parker N, Brand MD. Dynamic regulation of uncoupling protein 2 content in INS-1E insulinoma cells. Biochim Biophys Acta. 2008; 1777:1378-1383. [PubMed: 18692019]

96. Zhang CY, Baffy G, Perret P, et al. Uncoupling protein-2 negatively regulates insulin secretion and is a major link between obesity, beta cell dysfunction, and type 2 diabetes. Cell. 2001; 105:745755. [PubMed: 11440717]

97. Zhang CY, Parton LE, Ye CP, et al. Genipin inhibits UCP2-mediated proton leak and acutely reverses obesity- and high glucose-induced beta cell dysfunction in isolated pancreatic islets. Cell Metab. 2006; 3:417-427. [PubMed: 16753577] 
98. Kohnke R, Mei J, Park M, York DA, Erlanson-Albertsson C. Fatty acids and glucose in high concentration down-regulates ATP synthase beta-subunit protein expression in INS-1 cells. Nutr Neurosci. 2007; 10:273-278. [PubMed: 18284036]

99. Morgan NG. Fatty acids and beta-cell toxicity. Curr Opin Clin Nutr Metab Care. 2009; 12:117122. [PubMed: 19202382]

100. Oprescu AI, Bikopoulos G, Naassan A, et al. Free fatty acid-induced reduction in glucosestimulated insulin secretion: evidence for a role of oxidative stress in vitro and in vivo. Diabetes. 2007; 56:2927-2937. [PubMed: 17717282]

101. Holohan C, Szegezdi E, Ritter T, O'Brien T, Samali A. Cytokine-induced beta-cell apoptosis is NO-dependent, mitochondria-mediated and inhibited by BCL-XL. J Cell Mol Med. 2008; 12:591-606. [PubMed: 18081694]

102. Akerfeldt MC, Howes J, Chan JY, et al. Cytokine-induced beta-cell death is independent of endoplasmic reticulum stress signaling. Diabetes. 2008; 57:3034-3044. [PubMed: 18591394]

103. Matschinsky FM. Glucokinase, glucose homeostasis, and diabetes mellitus. Curr Diab Rep. 2005; 5:171-176. [PubMed: 15929862]

104. Zelent D, Najafi H, Odili S, et al. Glucokinase and glucose homeostasis: proven concepts and new ideas. Biochem Soc Trans. 2005; 33:306-310. [PubMed: 15667334]

105. Fridlyand LE, Philipson LH. Does the glucose-dependent insulin secretion mechanism itself cause oxidative stress in pancreatic beta-cells? Diabetes. 2004; 53:1942-1948. [PubMed: 15277370]

106. Produit-Zengaffinen N, Davis-Lameloise N, Perreten H, et al. Increasing uncoupling protein-2 in pancreatic beta cells does not alter glucose-induced insulin secretion but decreases production of reactive oxygen species. Diabetologia. 2007; 50:84-93. [PubMed: 17131143]

107. Wu L, Nicholson W, Knobel SM, et al. Oxidative stress is a mediator of glucose toxicity in insulin-secreting pancreatic islet cell lines. J Biol Chem. 2004; 279:12126-12134. [PubMed: 14688272]

108. Saitoh Y, Chun-ping C, Noma K, Ueno H, Mizuta M, Nakazato M. Pioglitazone attenuates fatty acid-induced oxidative stress and apoptosis in pancreatic beta-cells. Diabetes Obes Metab. 2008; 10:564-573. [PubMed: 17593232]

109. Ferre T, Riu E, Franckhauser S, Agudo J, Bosch F. Long-term overexpression of glucokinase in the liver of transgenic mice leads to insulin resistance. Diabetologia. 2003; 46:1662-1668. [PubMed: 14614559]

110. Kim JE, Kim YW, Lee IK, Kim JY, Kang YJ, Park SY. AMP-activated protein kinase activation by 5-aminoimidazole-4-carboxamide-1-beta-D-ribofuranoside (AICAR) inhibits palmitateinduced endothelial cell apoptosis through reactive oxygen species suppression. J Pharmacol Sci. 2008; 106:394-403. [PubMed: 18360094]

111. Moibi JA, Gupta D, Jetton TL, Peshavaria M, Desai R, Leahy JL. Peroxisome proliferatoractivated receptor-gamma regulates expression of PDX-1 and NKX6.1 in INS-1 cells. Diabetes. 2007; 56:88-95. [PubMed: 17192469]

112. Efanov AM, Sewing S, Bokvist K, Gromada J. Liver X receptor activation stimulates insulin secretion via modulation of glucose and lipid metabolism in pancreatic beta-cells. Diabetes. 2004; 53(Suppl 3):S75-78. [PubMed: 15561926]

113. Kim SY, Kim HI, Park SK, et al. Liver glucokinase can be activated by peroxisome proliferatoractivated receptor-gamma. Diabetes. 2004; 53(Suppl 1):S66-70. [PubMed: 14749268]

114. Kim HI, Ahn YH. Role of peroxisome proliferator-activated receptor-gamma in the glucosesensing apparatus of liver and beta-cells. Diabetes. 2004; 53(Suppl 1):S60-65. [PubMed: 14749267]

115. Choo HJ, Kim JH, Kwon OB, et al. Mitochondria are impaired in the adipocytes of type 2 diabetic mice. Diabetologia. 2006; 49:784-791. [PubMed: 16501941] 


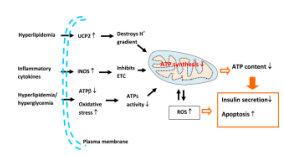

Figure 1. Association of reduced ATP synthesis in mitochondria with obesity-induced pancreatic $\beta$ cell dysfunction

Decrease in ATP synthesis is the central event in the progression of islet dysfunction under insulin-resistant conditions. UCP2: uncoupling protein 2; iNOS: inducible nitrogen synthase; ATP $\beta$ : ATP synthase $\beta$ subunit; ATPs: ATP synthase complex; ROS: reactive oxygen species; ETC: electron transport chain. 


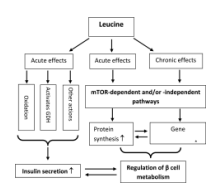

Figure 2. Leucine plays diverse roles in regulation of insulin secretion in pancreatic $\beta$ cell via acute and chronic effects

Further demonstration of the mechanisms by which leucine regulates GDH activity and upregulates other key metabolic genes will shed new light on prevention and treatment of type 2 diabetes. GDH: glutamate dehydrogenase; mTOR: mammalian target of rapamycin. 